\title{
State Governance Models in China: the Transformation and the Cooperation Mechanisms*
}

\author{
Chunxia Shao \\ School of Political Science and International Relations \\ Tongji University \\ Shanghai, China
}

\begin{abstract}
The reform and opening up starting in 1979 has promoted the transformation of China's state governance from revolutionization to routinization. After more than 30 years of continuous changes, under the dual promotion of reform deepening and the new media revolution, the actors and tools of state governance have diversified to great extent, thus entering the second transformation of governance model from administrative governance to cooperative governance. This process means that the socialized governance mechanisms gradually develop and complement administrative governance. Administrative governance is mainly based on the administrative cooperation within the system, while socialized governance relies on the societal cooperation mechanisms between political parties, government systems and other participating entities. While ensuring the government's dominant position, the new cooperative governance needs to absorb multiple societal forces more effectively and construct the effective cooperation mechanisms between the government system and the multiple governance entities.
\end{abstract}

Keywords-state governance model; administrative cooperation; societal cooperation; cooperation mechanisms

\section{INTRODUCTION}

With the continuous deepening and expansion of the reform and opening up, the multi-interests structure has gradually formed in Chinese society, and the mobilizing functions of various social organizations have gradually expanded, especially with the rapid rise of new cyber mobilization methods provided by information technology, the diversification of China's governance actor and the dispersiveness of mobilization process are increasingly strengthened. This is mainly reflected as follows: in the process of state governance, the political organizations still assume the core governance functions, and meanwhile various social organizations and market entities have gradually assumed important functions of providing public services and participating in socialized governance in various fields. At the same time, the diversification of interests and the dispersiveness of mobilization process have also led to the intensification of social conflicts and frequent problems in governance. In this context, to explore an effective model of state governance, it is necessary to pay attention to

*Fund Project: Philosophy and Social Science Series Project of Shanghai City, "Study on Promotion of Community Co-governance and Autonomy in Shanghai" (2012XAH004). absorbing the mobilization and governance forces of multiple actors outside the authority system and strive to construct a basic path of effective cooperation mechanisms among multiple governance entities. Based on the analysis of the two model transformations of China's state governance, this paper takes the administrative cooperation in crisis governance and the societal cooperation in environmental governance as examples and discusses how to construct an effective cooperative state governance model from the perspective of cooperation mechanism.

\section{Changes of the State Governance Models IN CHINA}

Since the founding of the power, communist China's state governance has experienced different modes: Firstly, the revolutionary governance with the vigorous mass movements as the main form has become the basic governing tool in political, social and economic construction since the early $1950 \mathrm{~s}$. Secondly, a major change of the state governance model brought by the reform and opening up is to return to the routinized management with the bureaucratic system as the major actor, and campaign-style governance is no longer the basic management model monopolizing the political and social space. The transformation from revolutionary governance to routine governance initiated by the reform and opening up is the first major transformation of China's state governance model. Thirdly, thirty years after the reform and opening up, the changes in social structure, the reform of governance system, and the multiple influences of information technology have further required the transition from administrative governance to socialized governance. This is the second major transformation that China's state governance system is currently experiencing.

\section{A. From Revolutionization to Routinization: the First Transformation of the State Governance Model}

The reform and opening up has opened up a rational path for China's political development, and the revolutionary governance that lasted for 30 years has gradually given way to routine governance. This is the first important transformation of China's state governance model. The distinction between the so-called "revolutionary" and "routine" governance models is mainly based on whether the state governance relies on the routine management of 
bureaucratic system. If we can say that the revolutionary governance is based on charismatic authority and has stronger features of rule by person, then the routine governance is more based on rational authority and constitutes an important part of the institutionalized political process.

The revolutionary governance is mainly based on leader's authority, which takes deviation from the routine bureaucratic system as the operation mode, the passive participation of the masses as the source of strength, and violence beyond the law as the backing, and has a typical revolutionary feature and strong arbitrariness. Defining state governance by "revolutionization" and using the meaning of "essential change" in the concept of revolution are to emphasize the intense and non-routine features of this mobilization model through the expanded use ${ }^{1}$ of the concept of revolution. The various mass movements initiated by the authorities before the reform are typical of revolutionary governance. ${ }^{2}$ In this sense, some movements initiated after the reform still have the features of revolutionary governance, such as the "Three Emphases" education, SARS crisis mobilization, "Strike-Hard" and various special rectifications.

Routine governance relies mainly on bureaucratic system and social organizations, and usually does not break the routine work order. Although the routine governance does not get effect as instantly as revolutionary governance, it operates within the institutional system and focuses on order stability, which is the normal way of state governance. After the reform and opening up, Chinese society has generally abandoned the violent revolutionary governance. For example, when Deng Xiaoping explained the problem of organization simplifying reform, he said: "This is a small movement, but not in a way of movement in the past." ${ }^{3}$ The "small movement" mentioned here is a means of routine governance.

\section{B. From Administrative Governance to Cooperative Governance: the Second Model Transformation in Progress}

The reform and opening up have led China's state governance system to a routine and institutional track. However, since the state governance from the reform is still

See the analysis of the three implications of revolution by Xue Hanwei et al. Xue Hanwei et al.: Study on Revolution and Constant Revolution, Lanzhou, Gansu People's Publishing House, 1984, P7-9.

Studies on China's mobilized governance are as follows: [United States] Kenneth Liberthal, translated by Hu Guocheng, Zhao Mei: Governing China: From Revolution through Reform, Beijing: China Social Sciences Press, 2010. Andrew G. Walder, translated by Gong Xiaoxia, Communist Neo-Traditionalism, Hong Kong: Oxford University Press, 1996. Feng Shizheng: The Formation and Variation of China's National Movement: A Whole Interpretation Based on Regime, Open Times, No. 1, 2011. Tang Huangfeng: Normal Society and Mobilized Governance: A Study of the "Strike-Hard" Policy in China's Social Security Governance, Open Times, No. 3, 2007. Zhou Xueguang: Mobilized Governance

Mechanism: Rethinking the Institutional Logic of China's State governance, Open Times, No. 9, 2012.

Deng Xiaoping: Organization Simplifying is a Revolution, in Selected Works of Deng Xiaoping, Shanghai, People's Publishing House, 1994, Vol. 2, P. 401 dominated by the state force, the positive potential in the society has not yet been fully utilized. The development of the mobilization means promoted by the social space and information technology released by the system reform increasingly highlights the problems of the administrative governance model, such as the singularity of actor and the lack of flexibility of the mobilization tools. The state governance faces the pressure of re-transformation.

If we say that the reform and opening up initiated more than 30 years ago have facilitated the transformation of the state governance system from revolutionization to routinization, then after more than 30 years of reform and opening up, under the dual promotion of institutional reform deepening and information technology development, China's state governance system inevitably enters the track of the second model transformation: from "administrative governance" to the "cooperative governance" combining administrative governance with "socialized governance". The so-called distinction between administrative and socialized governance (see "Fig. 1") is mainly based on the institutional or social characteristics of the governance actors. Specifically, administrative governance takes institutional powers such as national authority organizations as the actors, while socialized governance takes non-government societal forces as the actors. Due to the differences in resources owned by different types of actors, the two types of governance often adopt different paths: administrative governance is generally promoted by top-down power, while socialized governance relies mainly on bottom-up social promotion.

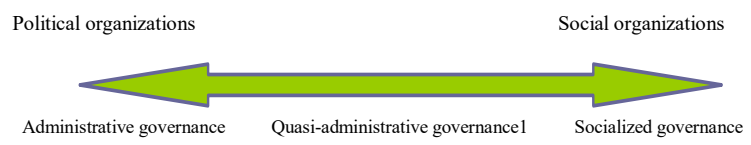

Fig. 1. Administrative governance, quasi-administrative governance and socialized governance.

Distinguishing between administrative governance and socialized governance helps to examine the contrast between state force and societal force in governance system, as well as the differences between governance methods in administrative orders and socialized mechanisms. Even the education and policy implementation movements after the reform, such as "Education to Keep Progressiveness", "Strike-Hard", SARS crisis mobilization, and even direct election reform of urban and rural mass autonomous organizations, etc., mobilize in an administrative model to great extent, let alone the various mass movements before the reforms. Administrative governance is the main mobilization method in China's current political and social life, which embodies the single main position of the government system in the process of state governance. Socialized governance is both promoted by social organizations and driven through social networks by scattered individuals. At present, China's socialized governance is mainly reflected in mobilization activities of charities, environmental organizations, rights protection organizations in their respective fields. With the development of internet media, impressive new forms of 
rapid interpersonal mobilization based on information dissemination technologies such as e-mail, Internet forums, Weibo, WeChat have emerged.

There are many expressions of this dichotomy of state governance, such as government-led mobilization versus social-led mobilization, rigid mobilization versus flexible mobilization, organizational mobilization versus market mobilization, power mobilization versus operational mobilization, linear mobilization versus matrix mobilization, mobilization in system versus mobilization outside system, community mobilization versus free association mobilization, in addition, there is also trichotomous summary of government mobilization, neighborhood mobilization and state governance under the dichotomy. ${ }^{4}$ This paper expresses this distinction by administration and socialization, mainly to emphasize the institutional characteristics and social attributes of the governance actors, which helps to reflect on the problems of the current administrative governance model that is in a dominant position.

The powerful position of China's state forces has made "cooperation" almost a one-man show of the government. Therefore, the transformation to cooperative mobilization means strengthening the power of socialized governance. If the "cooperation" in the single-actor model is mainly the cooperation between the various departments and levels within the authority system, the "cooperative governance" expands the space for cooperation between the state and social sectors, and integrates broader societal forces into the state governance system.

\section{ADMINISTRATIVE COOPERATION MECHANISMS IN CRISIS GOVERNANCE}

Administrative cooperation refers to the cooperation between the government and its affiliated systems, departments, and levels. In addition to the ruling party and government agencies, the actors of state governance also include various quasi-government institutions, such as people's organizations, state-owned enterprises and public institutions, the media, and urban and rural mass autonomous organizations. Since the social attributes of such institutions are restricted by their state attributes, this paper regards the cooperation between the party system and such quasigovernment agencies as the internal coordination of the government system on public affairs management. For example, the crisis governance against SARS is a national mobilization with the ruling party and the government system as the core, in which various political and social institutions and various mass organizations highly participated, typically reflecting the characteristics of China's

Wu Sihong: Rural Relations and Rural Governance under the System of Villager Autonomy, Journal of the National School of Administration, March 2003; Gui Yong: Neighbor Politics: The Power Operation Strategy of Urban Grassroots and the Adhesive Model of the State and Society, in Society, No. 6, 2007. Wang Jianqin: Developing NGOs is an Effective Way to Realize Broad Social Participation, People's Congress Studying, No. 9, 2005; Horizon Research Consultancy Group: Flexible Mobilization and Rigid Mobilization in Communities : From Separation to Integration (2000), horizonkey, http://www.horizonkey.com/showart.asp?art id=77\&cat id=6. administrative governance system. This paper mainly discusses the cooperation between the two levels of institution building and the mobilization implementation.

\section{A. The Organization System with Administrative Power as the Core}

After the outbreak of the crisis, the central government established the National Command for Prevention and Control of SARS to lead the national "anti-SARS" work. Wu $\mathrm{Yi}$, member of the Political Bureau, vice premier of the State Council and the Minister of Health, served as the chief commander. The command had 11 groups: prevention and control group, health and quarantine group, scientific and technological research group, logistics support group, rural group, publicity group, social security group, foreign affairs group, education group, Beijing group and "anti-SARS office". The main leaders of 10 functional departments, including the Ministry of Health, the AQSIQ, the Development and Reform Commission, the Ministry of Agriculture, the Central Propaganda Department, the Ministry of Public Security, the Ministry of Foreign Affairs, the Ministry of Education, the municipal government of Beijing, the State Council Secretariat, and 1 municipality directly under the Central Government served as the leaders of each group. Including the chief commander and the main leaders of each group, the command was composed of more than 30 people from departments and units such as the Party Central Committee, the State Council, the military system and Beijing City. ${ }^{5}$

In addition to national leading institutions, the ministries and commissions of the State Council, the provincial people's governments and their subordinate governments and subordinate units also established leading groups. For example, at the provincial level, the leader of the leading group was generally served by the governors of the province, and the deputy leader was served by the deputy secretary of the provincial party committee and the leader of the provincial military division; the provincial leading group had a leading group office as the daily office, generally composed of the leaders or deputy leaders of various departments and bureaus, so as to achieved effective leadership of the provincial government on its subordinate departments. In this way, the leading group, as an organizational form, went from the top to the bottom directly to the township governments. At the same time, in the various enterprise and public institution systems under the government, the leading group also set up various teams and departments.

This huge temporary organization system which traverses all levels of government and crosses all sectors of society breaks the original division of the party, government, enterprise and institution systems, strengthens the effective cooperation between departments, quickly integrates the

Notice of the General Office of the State Council on Establishing the National Command for the Prevention and Control of SARS, GUO BAN FA [2003] No. 35, see the State Council website:

http://www.gov.cn/gongbao/content/2003/content 62129.htm . Browsed on May 6, 2018. 
organizational strength of multiple functional departments and units, and plays an important coordinating role in organizing crisis mobilization throughout the country.

\section{B. Cooperation Mechanisms Supported by the Power Chain}

A strong organizational system provides a strong guarantee for smooth cooperation between governance actors. However, whether the policy can be effectively implemented at all levels and units and whether the mobilization process can be carried out in an orderly manner depend mainly on whether the government can effectively supervise and whether the various governance actors can well cooperate. All of this must be based on the effective cooperation mechanisms. Cooperation in crisis governance includes not only the vertical cooperation mechanisms between the levels, but also includes the horizontal ones between the party and government system and other departments.

The vertical cooperation mechanism refers to a set of power relations of mutual cooperation and their operation modes formed between different levels. The bureaucratic system of the party and government departments is the basic carrier of vertical cooperation. The interaction between command and obedience from the central to the local and to the grassroots constitutes the basic content of vertical cooperation. The temporary regulatory mechanisms established during the crisis further guarantees the efficiency of vertical cooperation from institution. For example, the State Council dispatches inspector group to inspect the epidemic in various places, inspect and supervise the implementation of prevention and control work, learn the social response and practical difficulties, and provide guidance and assistance to local prevention and control work. The main responsible persons of each place report the work situation to the inspection team listen to the guidance and revise the local prevention and control plan.

The horizontal cooperation mechanism refers to the operation mode of mutual cooperation between the party and government system and other political or social institutions. A typical manifestation of horizontal cooperation is that the government makes media play positive roles in mobilizing support for anti-SARS action from the society. On April 20, 2003, the State Council fully disclosed the epidemic for the first time, and the mainstream media immediately unloaded the burden and publicized a variety of relevant information to the public, such as epidemic notification, central deployment, and successful practices in each place and scientific prevention. In addition to information providing, the media also set up central issues for the public, such as strong measures by the party and the government; stay alert but don't panic; medical workers are heroes of the times; understand and care for SARS patients. Through information publicizing and appropriate setting of public issues, the media assisted the government in regaining the trust of the domestic and international communities and provided positive public opinions and social support for the government's extensive and in-depth state governance.
Typical horizontal cooperation also includes interaction between the party and government system and other social sectors. For example, the China Charity Federation, the China Red Cross and other non-profit organizations actively raised funds and provided financial support; the Communist Youth League organizations, food and other service industry associations published promotional materials to provide knowledge assistance for anti-SARS work, and advocated enterprises to strictly self-discipline in health measures. The localized management systems in some areas also promoted such cooperation from the institution. For example, more than 3500 resident committees in Shanghai set up "antiSARS" supervisors to train people at densely populated places nearby, such as hotels, restaurants, and net bars; and all units under the jurisdiction of each district and county, regardless of the administrative subordination, accepted the unified arrangement of the district and county party committees and governments.

In the whole process of mobilization, in terms of the power relationship, whether it was vertical or horizontal cooperation, it was maintained in the chain of state power and had certain mandatory characteristics. In terms of the actors of governance, the party and government system was the dominant force in the cooperative relationship. The role of the social system was mainly reflected in the obedience and support of the managed and the lack of sufficient capacity for independent participation.

\section{Limited Participation of Civilian Societal Forces}

Although cooperation between the government and society is in a secondary position in the mobilization process, non-governmental societal forces still attempted and accomplished something during the entire crisis mobilization process. In fact, some non-governmental organizations and individuals, such as the China Social Work Association, and other non-profit organizations, community organizations and volunteers actively participated in mobilizing social resources and assisting government actions.

This crisis mobilization was carried out from the top down. The ruling party, the government and their affiliated organizations monopolized the protagonists of the antiSARS stage, while the role of civil non-governmental organizations was limited to small scale of fund raising and services, and could not play a more important role in a global context. At the same time, the phenomena such as merchants arbitrarily rising prices, citizens rushing to buy, villagers violently preventing people returning to hometowns or passing by, and people cutting off national highways to stop people coming from the infected areas exposed the weak civic awareness in society and the limited social selforganization ability. ${ }^{6}$ The lack of function of the nongovernmental organizations and the lack of civic awareness indicate that the Chinese society at that time was still a passive and less organized society, and such a society could

\footnotetext{
6 Gao Xiang: The Development of Chinese Civil Society Reflected by the SARS Crisis, chief edited by Hu Angang, Perspective of SARS Health and Development, Tsinghua University Press, 2003, P287-308
} 
not fully promote more active cooperation with the government.

\section{SOCIETAL COOPERATION MECHANISMS IN ENVIRONMENTAL GOVERNANCE}

The societal cooperation mechanisms jointly constructed by the government and societal forces refers to the interaction and cooperation between the government authority system and its external social system. The government authority system includes the ruling party, the government and their subsidiary systems; the social system mainly includes various non-governmental organizations, public groups and individual citizens. Although the cooperation between civil social organizations and government authority systems is mainly partial, the fact that the government cooperates with societal forces undoubtedly expands the scope of public affair governance, and will gradually promote the formation of societal cooperation mechanisms. Next, it will be explained by the cases in which non-governmental environmental protection organizations and government departments cooperated to promote "shelving Nujiang dam construction plan" 7 and the "EIA Storm",

\section{A. Alliance Between the Government and Non- governmental Organizations}

The main government actor of these two environmental governance actions was the former State Environmental Protection Administration (upgraded to the Ministry of Environmental Protection in the institutional reform of the State Council in 2008, reorganized into the Ministry of Ecology and Environment in 2018. The name of the former institution at the time when the case occurred will still be used below, referred to as "the State Environmental Protection Administration"), and the societal actors mainly included non-governmental environmental organizations such as the Green Home Volunteers, Yunnan Dazhong Watershed, Friends of Nature and Global Village, and paper media such as Beijing Youth Daily and Beijing News, and their opponents were the local governments, large stateowned enterprises, the National Development and Reform Commission and other departments that attached importance to project benefits. In the process of mobilization, both the government's environmental protection departments and nongovernmental organizations took the initiative to seek support from each other, and mutually strengthened the functions of each other in the cooperative governance.

For related information and data, see Deng Jin: The New Force of Environmental Protection Comes, Southern Weekly, January 27, 2005. Shi Jie: Perspective of the Tripartite Interest Game Democracy in the Decision-making Process of Nujiang Hydropower Project, International Herald Leader, April 20, 2004.

Related information and data are from the website of the State Environmental Protection Administration of the People's Republic of China, Http://www.sepa.gov.cn/hjyw/hpfb/200502/t20050225 64644.htm (February 2005);

Http://www.sepa.gov.cn/hjyw/hpfb/200501/t20050131_64114.htm (January 2005)
On the one hand, non-governmental organizations actively established supportive relations and partnerships with government departments. In the mobilization process of "shelving Nujiang dam construction plan" and the "EIA Storm", non-governmental environmental organizations relied on the media to gain public support, and actively cooperated with the State Environmental Protection Administration to obtain strong social support. It was through active cooperation with government departments that environmental organizations were more likely to obtain government resources and institutional support, thereby achieving their own mobilization goals more effectively. As Liao Xiaoyi, head of the Global Village, pointed out, as a non-governmental environmental protection organization, they "never think about not cooperating with the government"

On the other hand, the government actively cooperated with non-governmental organizations to obtain support for resources such as public opinions and technical knowledge. Under the development background dominated by economy, environmental supervision became the constraint of some engineering projects. Driven by interests, relevant local governments, functional departments and enterprises evaded or even hindered the supervision and coordination of the environmental protection departments. At that time, the decision-making status of the State Environmental Protection Administration, which was directly under the State Council, was lower than that of the Ministries and Commissions of the State Council, and it only had the operational guidance authority on local environmental protection bureaus, which made it difficult to interfere with the local government's behaviors through administrative power. Therefore, in the face of weak power and arduous tasks, it was very necessary to seek for support from societal forces. In the process of shelving Nujiang dam construction program, the State Environmental Protection Administration directly sought support from non-governmental organizations for technical experts and public opinions, so that the voice of nongovernmental organizations could smoothly enter the policy agenda and ultimately affect the decision-making of the central government. This mobilization incident made the government's environmental protection department further aware of the importance of public participation, and thus promoted the idea of taking non-governmental organizations as "alliance forces". Pan Yue, deputy director of the State Environmental Protection Administration at that time, stressed the roles of the alliance forces: "In the face of a number of construction projects, merely the government supervision is obviously not enough." So it was necessary to "contact and unite the media, scholars, people's congresses, CPPCC, NGO, and the people to form alliance forces."10

\footnotetext{
Liao Xiaoyi: Study on the Strategies of Non-governmental Environmental Organizations Advocating Public Participation in Environmental Protection, Xuehui, No.5, 2005.

10 Deng Jin: The New Force of Environmental Protection Comes, Southern Weekly, January 27, 2005.
} 


\section{B. Government-led Cooperation Mechanisms}

The successful mobilization of shelving Nujiang dam construction plan and the EIA Storm was seen as a model for Chinese non-governmental environmental organizations participating in state governance and influencing public policies. But these mobilizations also showed that the key to the success of non-governmental organizations was to find partners with common ideas inside the government. The core role in the success of environmental mobilization was the officials of the State Environmental Protection Administration ${ }^{11}$, this evaluation accurately revealed the essential characteristics of the cooperation mechanisms between the State Environmental Protection Administration and the non-governmental environmental protection organizations: this was a government-led societal cooperation.

From the survival to the different stages of participation in mobilizing process of non-governmental environmental organizations, the State Environmental Protection Administration played a key role. As far as the survival of environmental organizations was concerned, the "dual management system" 12 and the "non-competition principle" 13 of the associations made it difficult for some non-governmental organizations to obtain the legal status they deserved. For example, the famous environmental protection organization "Green Home Volunteers" found it difficult to formally register for a long time; the "Friends of Nature" officially registered with the Ministry of Civil Affairs faced pressures for survival due to problems with the business administrative departments. In this regard, the State Environmental Protection Administration endeavored to provide assistances, emphasized the important roles of nongovernmental associations in environmental protection, ${ }^{14}$ and promoted the government's recognition of the status of these non-governmental organizations. ${ }^{15}$ In terms of the specific process of environmental protection organizations participating in environmental mobilization, the State Environmental Protection Administration, in addition to the main functions of drafting regulations, conducting environmental impact assessments, supervising development activities and other environmental protection businesses, also promoted the participation of the public and non-

11 Xu Xiaoying: Alliance between Chinese NGO and Government, Business Watch Magazine, March 20, 2005.

12 The so-called "dual management" means that social organizations must accept the dual leadership of the administrative departments, and have two "mothers-in-laws", namely "registration management organs" and "business administrative departments" at the same time. The legal basis is Articles 6 and 9 of the Regulation on the Administration of the Registration of Social Organizations.

13 The "non-competition principle" refers to the establishment of a similar new organization will not be approved when "there has been a social organization with the same or similar business scope in the same administrative region". The legal basis is Article 13 of the Regulation on the Administration of the Registration of Social Organizations.

14 Xu Xiaoying: Alliance between Chinese NGO and Government, Business Watch Magazine, March 20, 2005.

15 Decision of the State Council on Several Issues Concerning Environmental Protection (August 3, 1996), Xinhuanet, http://news.xinhuanet.com/ziliao/2005-03/14/content 2696239.htm. governmental organizations in environmental protection management and coordination tasks.

\section{Cooperation Mechanisms with Elites as the Link}

The cooperation mechanisms between government and social organizations formed in environmental mobilization was largely based on the cooperation between government officials and heads of non-governmental organizations. It was based on the common environmental protection concept and private friendship among the elites, and was very personal. There has been no institutionalized cooperation mechanism between the government and social organizations.

In term of government elites, Pan Yue, the deputy director of the State Environmental Protection Administration in charge of environmental impact assessment at that time, once worked in the media for a long time as the reporter team leader of China Environment News, deputy editor-in-chief of China Technology Supervision News, and the deputy editor-in-chief of China Youth Daily. The working experience in the media made him have both rational cognition and work enthusiasms for China's environmental protection issues as a government official. Pan Yue's rich resources accumulated over the years helped the State Environmental Protection Administration to maintain good communication with the news media and win more social support for the work of the State Environmental Protection Administration. At the same time, his commitment to environmental protection also led him to establish close ties with the leaders of non-governmental environmental organizations. In addition, the friendship between Mou Guangfeng, director of the Environmental Assessment Department of the State Environmental Protection Administration at that time, and the heads of several non-governmental environmental protection organizations greatly promoted the smooth cooperation between them. $^{16}$

In terms of the elites of non-governmental organizations, Liang Congjie, the head of the Friends of Nature, Wang Yongchen, the head of the Green Home Volunteers, and Liao Xiaoyi, the head of Beijing Global Village, had high visibilities and influences in the fields of environmental protection, journalism and academics. Their personal charms were vital to the development of environmental organizations. Their friendly relationship with the government was a key factor in smoothly carrying out activities, cooperating with the government, and even protecting from inappropriate government intervention. For example, Liang Congjie was a historian and descendant of an eminent family (He is Liang Sicheng and Lin Huiyin's son. ), and he was also a member of the national committee of CPPCC, which had a positive effect on the Friends of Nature in obtaining support and establishing cooperation in the environmental mobilization.

It is undeniable that the cooperative mobilization mechanisms built based on the influences of elites are

16 Xu Xiaoying: Alliance between Chinese NGO and Government, Business Watch Magazine, March 20, 2005. 
effective for realizing the environmental protection goals. However, the cooperation mechanisms based on personal connections are lack of sufficient stability. Only institutionalized cooperation mechanisms can make social organizations free from dependence on elite individuals.

\section{CONCLUSION}

The analysis of crisis governance and environmental governance above shows that in addition to the administrative cooperation mechanisms between various departments inside the system, China's state governance has also formed societal cooperation mechanisms between the government and non-governmental organizations, so that many actors have the opportunities to participate in the process of state governance. However, in the current state governance system, not only the administrative cooperation mechanisms are more common than the societal ones, but also the societal cooperation mechanisms lack sufficient stability due to the lack of institutional support. Therefore, although multiple participants are involved in the process of state governance to varying degrees, the constitution of state governance actors still takes political parties and government authority systems as a single central force and the participation of societal forces are relatively limited.

Therefore, to promote the transformation of the administrative governance model to societal cooperative governance model, it is necessary to further develop socialized governance and promote the cooperation and mutual improvement between socialized governance and administrative governance, thereby more effectively responding to the new challenges in state governance in the information era. At the policy level, a series of decisionmaking considerations for cooperative governance should be established: including adjusting policy ideas, controlling administrative interventions, striving to build a multi-actor cooperation network involving political parties, governments, social organizations, and the public, and promoting the establishment of cooperative governance models. Multi-actor cooperative governance emphasizes the different forces from the government and society to complement functions and mutually improve strengths. Under the current conditions, this idea breaks away from the confrontation between the government and the society, emphasizes the introduction of more societal forces to participate, enhances societal mobilization, and realizes the transformation of the cooperative governance model by establishing complementary mechanisms of administrative and socialized governance, thereby effectively integrating different governance forces from the government and society.

\section{REFERENCES}

[1] Xue Hanwei et al. Xue Hanwei et al.: Study on Revolution and Constant Revolution, Lanzhou, Gansu People's Publishing House, 1984, P7-9. (in Chinese)

[2] [United States] Kenneth Liberthal, translated by Hu Guocheng, Zhao Mei: Governing China: From Revolution through Reform, Beijing: China Social Sciences Press, 2010.

[3] Andrew G. Walder, translated by Gong Xiaoxia, Communist NeoTraditionalism, Hong Kong: Oxford University Press, 1996.
[4] Feng Shizheng: The Formation and Variation of China's National Movement: A Whole Interpretation Based on Regime, Open Times, No. 1, 2011. (in Chinese)

[5] Tang Huangfeng: Normal Society and Mobilized Governance: A Study of the "Strike-Hard" Policy in China's Social Security Governance, Open Times, No. 3, 2007. (in Chinese)

[6] Zhou Xueguang: Mobilized Governance Mechanism: Rethinking the Institutional Logic of China's State governance, Open Times, No. 9, 2012. (in Chinese)

[7] Deng Xiaoping: Organization Simplifying is a Revolution, in Selected Works of Deng Xiaoping, Shanghai, People's Publishing House, 1994, Vol. 2, P. 401(in Chinese)

[8] Sun Liping: Mobilization and Participation: A Case Study of the Third Sector Mobilization Mechanism, Hangzhou: Zhejiang People's Publishing House, 1999. (in Chinese)

[9] Wu Sihong: Rural Relations and Rural Governance under the System of Villager Autonomy, Journal of the National School of Administration, March 2003. (in Chinese)

[10] Wang Jianqin: Developing NGOs is an Effective Way to Realize Broad Social Participation, People's Congress Studying, No. 9, 2005(in Chinese)

[11] Gui Yong: Neighbor Politics: The Power Operation Strategy of Urban Grassroots and the Adhesive Model of the State and Society, Society, No. 6, 2007. (in Chinese)

[12] Gao Xiang: The Development of Chinese Civil Society Reflected by the SARS Crisis, chief edited by Hu Angang, Perspective of SARS: Health and Development, Tsinghua University Press, 2003, P287-308. (in Chinese)

[13] Xu Xiaoying: Alliance between Chinese NGO and Government, Business Watch Magazine, March 20, 2005. (in Chinese)

[14] Liao Xiaoyi: Study on the Strategies of Non-governmental Environmental Organizations Advocating Public Participation in Environmental Protection, Xuehui, No.5, 2005. (in Chinese)

[15] Deng Jin: The New Force of Environmental Protection Comes, Southern Weekly, January 27, 2005. (in Chinese)

[16] Shi Jie: Perspective of the Tripartite Interest Game Democracy in the Decision-making Process of Nujiang Hydropower Project, International Herald Leader, April 20, 2004. (in Chinese) 